\title{
Book Reviews/Comptes rendus
}

Ronald M. Steinberg. Fra Girolamo Savonarola, Florentine Art, and Renaissance Historiography. Athens, Ohio: Ohio University Press, 1977.Pp. 151. \$11.

Professor Steinberg deals with the influence, alleged and real, that was exerted on Renaissance artists by the Dominican preacher Girolamo Savonarola (1452-98), the prophet of doom, penitence and reform who, as legend has it, was responsible for firing the Florentines with religious zeal at the end of the fifteenth century. Acutely aware that any interpretation of the monk, or of his effect on contemporaries, is intimately bound up with each critic's view of the Renaissance and vantage point in history, Steinberg, well versed in the literature on the Renaissance controversy, describes the distorted myths created by early biographers of Savonarola and the unfounded embellishments in Vasari's account of artists' lives. He concentrates especially on the misinterpretations stemming from the nineteenth century when a predilection for simple Christian art gave impetus to the theory of a pagan Renaissance converted by Savonarola.

On the basis of modern scholarship, however, Steinberg correctly assumes that, as fascinating an individual as Savonarola may have been, he was no exception in his ige and that indeed the Italian Renaissance was at all times Christian. Therefore, te logically deduces, one must no longer assume that every artist who treated religious themes or was a follower of Savonarola in his personal life necessarily roduced paintings that can be labelled Savonarolan. Similarly, works commemorating Savonarola, including medals, represent a category apart and are appropriately dealt with in a separate but overly succinct chapter.

Steinberg traces the causes of the weaknesses in previous assessments of Savonarola's influence, especially that on Botticelli, Fra Bartolomeo Della Porta, and Michelangelo. He finds that a priori assumptions (such as the erroneous belief that an organized school of artists existed in Savonarola's monastery in San Marco), simple errors in chronology and false deductions had produced a faulty picture.

To correct this Steinberg proposes a superior method of criticism, an "interpretive visual analysis," which is designed to show what elements are distinctively Savonarolan in the paintings of the period by comparing the iconography in them to the themes and images that recur in Savonarola's own sermons, treatises and poetry. Steinberg first provides a clear exposition of Savonarola's theory of art l lased on the principles of didacticism, simplicity and naturalness and on the tenet 


\section{4 / Renaissance and Reformation}

that art must serve God, but realizing that it is hazardous to identify mere simplicity of style, for example, as an exclusively Savonarolan feature, he prefers to adopt as his criterion for judgment the concrete language, enlivened with verbal and visual images borrowed from everyday life, that Savonarola favoured in conveying abstract concepts to his audience.

Tracing these in specific works of art, Steinberg allows us to catch a glimpse of his mastery of the art historian's craft, for, in addition to weighing others' interpretations carefully, he offers keen insights of his own that are made easily intelligible with the help of black-and-white reproductions of the paintings under examination. It is regrettable, though, that a greater number of such acute critical appreciations are not included. But the results of Steinberg's investigation indicate that in only a handful of paintings can one detect Savonarola's influence. Botticelli's "Mystic Crucifixion," for instance, represents the embracing of the Cross (a typical Savonarolan theme) by a purged penitent, Mary Magdalen, who can also stand for the cleansed Church. The dark cloud in the sky is a sign of the tribulations announced in Savonarola's prophecies, and the lion or marzocco in the act of being struck is a symbol for Florence that will be chastised, as Savonarola often warned. Steinberg also includes in his drastically reduced list of Savonarolan works Botticelli's "Mystic Nativity"; Fra Bartolomeo's "Mater Misericordia" that repeats Savonarola's image of a bird-like Christ; his large altarpiece portraying "God the Father, Saint Mary Magdalen, and Saint Catherine of Siena," a visual depiction of divine contemplation as verbalized by Savonarola; and, finally, his "Madonna and Child with Saint Anne and Other Saints" that, designed for the Hall of the Great Council, symbolizes the new liberty gained after the overthrow of the Medici tyrants and the reestablishment of the reign of Christ, through Savonarola, in Florence.

Steinberg's complete dismissal of Michelangelo from the group of Savonarolan artists, however, is somewhat hasty and unconvincing. He rejects the views that former critics including De Tolnay have put forth, but provides no detailed analysis of the master's works to prove his independence from Savonarola.

Moreover, this study, primarily devoted to pinpointing flaws in earlier works, is not without its own shortcomings, particularly in the area of style and documentation. Although only a slim book, it is divided into fifteen of the briefest of chapters and even the style is so synthetic as to become at times telegraphic, especially in the first pages. Phrases such as "Savonarola's San Marco 'School of Art" (p. 5) and the ever-recurring words, "the literature," instead of a varied paraphrase, together with the undue number of cross-references included, it would seem, to avoid what would often be welcome explanations, illustrate this point. Greater revision might have eliminated the inconsistencies in the citing of names and book-titles, and the misspelling of Italian and French words (e.g. brucciamento, arrabiati etc.) as well.

The background information Steinberg provides would have been more complete too had he consulted the copiously annotated Italian edition of Ridolfi's biography of Savonarola that appeared in 1974. The evidence Ridolfi brings to bear on the question of the notorious burning of vanities, and on Savonarola's efforts to save the library of San Marco, could well have supported Steinberg's own contention that Savonarola was no cultural iconoclast. And although Steinberg does improve upon the ways of his predecessors by studying the original texts, rather than anthological gleanings, he fails to mention the two most recent additions to the publication 
of Savonarola's opera omnia. One wonders whether the volumes in question might not reveal clues to additional instances of Savonarola's influence.

Nevertheless, these blemishes do not mar the fundamental effectiveness of Steinberg's work. His main purpose and achievement is to point the way to a surer method of identifying and measuring Savonarola's real influence on art. He has done much to separate fact from fiction, insofar as truth and objectivity are possible, of course, and he has helped to rectify the antiquated image of Savonarola. For this he is to be thanked and his book, in spite of its lack of polish, can be set up as a model for further fruitful research.

\section{OLGA Z. PUGLIESE, University of Toronto}

XVIIe Colloque International de Tours. Théorie et Pratique Politiques à la Renaissance. Paris: Librairie Philosophique J. Vrin, 1977. Pp. 503.

Dans ce tome de 503 pages, les organisateurs du XVIIe Colloque international de Tours du Centre d'Etudes Supérieures de la Renaissance ont pris l'initiative de publier tous les textes des communications. Sur le thème général Théorie et pratique politiques à la Renaissance, ils ont divisé les trente-deux conférences en sous-thèmes: "Expériences exemplaires", "Expériences institutionnelles", "Opinion publique", "Influx littéraires", "Elaboration humaniste", "Synthèse".

Parmi les communications présentées, certaines reprennent les sentiers battus pour ajouter plus d'informations, de faits ou de rectifications aux événements, institutions ou personnages déjà connus; c'est notamment le cas dans les études médiocres sur l'Election impériale de 1519, de H. Weber; l'Etat corporatif hongrois, de G. Bonis, ou l'Organisation et le rôle politique des dietes dans les pays des Habsburg, de K. Benda. Dans plusieurs communications littéraires on essayait, avec plus de succès, de compléter ou de rectifier l'image d'un théoricien; F. Secret notait que le Guillaume Postel qui se dégage de Magistratibus Athenieusium est foncièrement différent de celui décrit par Pierre Mesnard ou William Bouwsma; B. Guillemain maintient que le Discours de Logrogno, de Guichardin, diffère notamment du Dialogo ou Ricordo si souvent étudiés, et laisse voir un personnage beaucoup plus humaniste. D'autres textes, plus ambitieux, se sont servis d'approches originales pour dégager des thèmes et des associations de mots qui révèlent des bases psycho-sociales de la Renaissance. Ce fut le cas de Jean Delumeau qui a démontré un contenu social dans l'optique des écrivains de la Renaissance devant les concepts de courage et de peur; le courage s'identifie à la prouesse militaire et aux actions individuelles des nobles, tandis que la peur et la lâcheté correspondent au travail productif et corporatif des vilains. De même, A. Jouana a étudié les attaques dirigées contre la noblesse à la fin du XVIe siècle et qui traitaient de l'application du concept d' "utilite"; critère que le Second état refusait et qui a été de plus en plus identifié au progrès de la bourgeoisie.

Enfin dans une autre catégorie d'études, les auteurs ont entrepris d'explorer le fossé qui séparait les humanistes et la réalité; la dialectique permanente entre, d'une part, les théories, théoriciens et hommes d'état et, d'autre part, les événements, l'opinion publique et la mentalité populaire. Dans un travail très bien documenté Claude Sutto a étudié les pamphlets anti-jésuites pour démontrer, d'une part, les 